\title{
Gender and Age Patterns on WhatsApp Statuses as Used by Jordanians: A Sociolinguistic Perspective
}

\author{
Ala'a Mohammad Al-Smadi ${ }^{1}$ \\ ${ }^{1}$ Department of Basic Sciences, Al-Balqa' Applied University, Allan, Jordan \\ Correspondence: Ala'a Mohammad Al-Smadi, Department of Basic Sciences, Al-Balqa' Applied University, \\ Allan, Jordan. E-mail: lolasmadi@yahoo.com
}

$\begin{array}{lc}\text { Received: March 6, } 2017 \quad \text { Accepted: April 7, } 2017 \quad \text { Online Published: July 15, } 2017 \\ \text { doi:10.5539/ijel.v7n4p56 } & \text { URL: http://doi.org/10.5539/ijel.v7n4p56 }\end{array}$

\begin{abstract}
This study aims at investigating the WhatsApp statuses as used by Jordanian people from a sociolinguistic point of view. It attempts to examine the use of the WhatsApp statuses in relation to the impact of gender and age on the topic being used. To achieve this goal, 400 statuses were collected from Jordanian males and females who are divided into two main age groups: the first one consists of participants whose age is above 30 years old, and the second group whose participants are under 30 years old. Then, the data were analyzed quantitatively and categorized based on the main following topics; religious, social, political, economic and fixed statuses. The results show that gender and age have essential impacts on the statuses being used. For example, the religious statuses are the most frequently used topic by Jordanian females whereas the social statuses are the most frequently used topic by Jordanian males. However, the political and economic statuses are the least frequent statuses used among Jordanian. Moreover, the results show that the most frequently used topic among males who are above 30 years old is the fixed statuses suggested by the mobile itself whereas the most frequently used topic among males who are under 30 years old is the social topic. On the other hand, the impact of age among females is clearly manifested in the use of the fixed statuses suggested by the mobile itself. For instance, the females who are above 30 years old use the fixed statuses more dramatic than the females who are under 30 years old. Also, the fixed statuses are the second frequently used topic by the females who are above 30 years old whereas they are the third frequently used topic by females who are under 30 years old.
\end{abstract}

Keywords: age, gender, Jordanian, sociolinguistics, status, whatsapp

\section{Introduction}

The world has been witnessing a huge revolution in the use of mobile phones. Mobile technology has spread rapidly throughout the world faster than any other communication technology, and is now widely used everywhere. The basic concept of mobile phones began in 1947 when researchers started developing car phones, but it was not until around 1982 that mobile phones, as we know them, were first used (Crystal, 2001).

The mobile did not immediately become "a device for the masses", and it was not widely spread in Jordan until the end of 1990's. Within a span of 10 years, from 1991 to 2003, the mobile telephony has moved from being the technology for a privileged few to essentially a mainstream technology (Castells, Fernandez-Ardevol, Qiu, \& Sey, 2006).

Mobile phones have been praised for "liberat(ing) individuals from the constraints of their settings" to facilitate being in multiple locations at one time (Katz \& Aakhus, 2002). For example, for work situations, multitasking, or in emergencies, calling the police, or, in simple everyday relations between family and friends, a heightened and flexible means for staying in touch and increased sense of belonging or contact on the other (Lamoureaux, 2011). The mobile phone is a significant social and cultural phenomenon which is highly symbolic for boys and girls alike since it represents reachability and popularity (Klimsa et al., 2006).

In Jordan, as is the case worldwide, the mobile phone has turned to be a social tool from that of a technological one as it really becomes an essential component of adolescents' daily activities as the most widely liked or appreciated form of communication. Being a social device, mobile phones can be used in positive ways to organize and maintain the users' social networks, and thus do have impacts on family relations in addition to its new function or role of shaping the youth mutual dealings and connections (Al-Azzam \& Al-Quran, 2009). Also, 
the authors suggest that as technologies go, mobile phones are flexible and provide coverage to homes and workplaces since people carry them as they move from place to place and between different social situations. These moving handsets shift time and place and further complicate contexts and roles since they enable and strengthen social and economic relations at a distance. Thus, mobile phones can be used for both productive and personal purposes throughout the users' daily routines.

The new smart mobile phones provide people with various applications that enable them to keep in touch with their friends, relatives, colleagues and so on and to preserve their sociability. One of these famous applications is the WhatsApp Messenger. It is worth mentioning that WhatsApp Messenger is a proprietary, cross-platform instant messaging subscription service for smart phones and selected feature phones that uses the Internet for communication. In addition to text messaging, users can send each other images, video, and audio media messages as well as their location using integrated mapping features. WhatsApp Inc. was founded in 2009 by Brian Acton and Jan Koum, both former employees of Yahoo!. As of October 2014, WhatsApp is the most globally popular messaging app with more than 600 million active users (http://www.whatsapp.com).

The widespread use of the mobile phones service and the social- cultural impacts that they have on people's life inspire the researchers to shed the light on the language being used on the mobile and the socio-cultural implications that they may denote. For example, Al Rousan, Abdul Aziz, \& Christopher (2014) examine the communicative functions of the text messaging of young Saudi university students. They suggest that there are five main categories of communicative functions found in Saudi undergraduate text messaging which are friendship maintenance, socialization, school collaboration, coordination, and exchanging information. Also, they point out that via text messaging, students can maintain and strengthen their existing friendship, as well as start new ones. They can also stay connected and socialize with their text messaging social network and family members through chatting and gossiping. The study also indicates that text messaging is used beyond its original purpose which is staying in social contact. It proves text messaging to be significant for students' school affairs. Not only does this medium of communication help young people plan and coordinate times and events, it has become one important source of information.

Al-khatib \& Sabbah (2008) examine the linguistic structure and sociolinguistic functions of English code-switching in mobile text messages as used by a group of Jordanian university students. The study reveals that there are a number of technical elements that might be responsible for the wide use of English or switching between English and Arabic "with Arabic Roman scripts" in mobile text messaging. Also, the data indicates that code switching could be brought about and shaped by the dynamics of the relationship of the speaker-addressee and by cultural features embedded in the Arabic language. The analysis also shows that code switching in this particular means of communication functions as a communicative strategy for facilitating communication by lowering language barriers as well as by consolidating cultural identity. Moreover, it has been noticed that the process appears to be conditioned, among other factors, by the sex of the writer.

Particularly, the social mobile application "WhatsApp" has inspired researcher to investigate its linguistic aspects. For example, Al Shezawi (2012) in the 11th Annual Research Conference which was held in the University of Birmingham discussed her study, which has the title of "The Effectiveness of Arabic and English Code-Switching Using WhatsApp Mobile Program. Two groups of Omani females", examines the effectiveness of switching to English while chatting in Arabic using WhatsApp mobile program to mitigating, softening, hiding or expressing certain feelings and many other reasons that are found from analyzing the chatting of two groups of friends and family on WhatsApp mobile program. This study aims to enhance the importance of switching to English in adding more meaning or expressing certain feelings in a different way that Arabic can do. The study shows that switching between Arabic and English in one chatting is healthy and interesting unlike the against believes of some Omanis who see it as unhealthy and has a negative effect on the purity of Arabic language.

Moreover, Badran (2014) investigates the linguistic conventions of English texting sent at Jordanian society by Jordanian females via WhatsApp. Also, she investigates the syntactic and morphological variations of texts messages written by Jordanians. The results show that English texting by Jordanian females has syntactic and morphological realizations that are appreciated and understood by Jordanians, such as omissions of apostrophe, use of abbreviations, adding sounds, and above all applying morphological creativity in adding Arabic words in Latin alphabets. In addition, Jordanian females stick to the English language order, and subject-verb agreement while texting.

The previous brief previews of the related literature give the privilege for this study as far as the researcher knows to be the first study that investigates the WhatsApp statuses from the sociolinguistic point of view in 
general. Also, it is supposed to be the first study that investigates the statuses being used among Jordanians people in particular. Therefore, this study aims to fill the gap in this topic.

\section{Objectives of the Study}

This paper aims at investigating the WhatsApp statuses among Jordanian people from a sociolinguistic point of view. It attempts to examine the use of the WhatsApp statuses in relation to the impact of gender and age on the topics being used. For example, social, political, religious, economical or the fixed statuses that are suggested by the mobile itself. Moreover, the study sheds the light on the most and least frequent statuses used by males and females from the two age groups.

\subsection{Research Questions}

This paper is designed to answer the following questions:

1). What are the topics used by males and females in their WhatsApp statuses?

2). How do differences in gender and age affect the topics used in WhatsApp statuses?

\section{Methods}

\subsection{Data Collection}

To achieve the goal of this study, 400 statuses were collected randomly from 400 Jordanian participants who have WhatsApp accounts. The participants were chosen from both genders (males and females) and from two age groups; the first group who are older than 30 years old, and the second group who are younger than 30 years old. It is worth mentioning that the statuses were equally divided in numbers to both males and females since the gender is vital for this study. The equality in number ought to provide us with accurate results. The participants belong to different social classes and they have different educational backgrounds. The data were collected from different sources which are: the list of the contacts on the researcher's mobile who have WhatsApp messenger, some of the researcher's friends, relatives, and work mates volunteered to collect some statuses to help in completing the process of the collection, and from the students whom the researcher is their teacher i.e., the researcher followed the "social network" model, suggested by Milroy \& Milroy (1978), and approach the subjects with the help of the assistants in the capacity of "a friend of a friend" or in some cases through "a friend of a friend's friend" (see also Al-Khatib \& Sabbah, 2008).

\subsection{Data Analysis}

After the 400 statuses were collected, they were categorized according to their topic into five main issues: social, religious, political, economic, and the fixed statuses. Further, the religious topic was divided into four subcategories which are; Prayers, Quranic verses, Prophet Mohammad's Sayings "Hadith", and Islamic phrases. The social topics were divided into two subcategories which are: emotional feelings statuses and wisdoms. The fixed statuses which are suggested by the mobile itself are: available, busy, At work, sleeping, Hey there! Am using WhatsApp. After that, the data were analyzed quantitatively into two variables: age and gender. Statistics were utilized to introduce the distribution of the statuses of males and females by topics and age.

\section{Findings and Discussion}

This section is designed to analyze the collected data and discuss the findings. It aims at answering the research's questions where each of the questions is addressed and discussed in a separate section. Statistics were utilized to introduce the distribution of the statuses of males and females by topics and age.

\subsection{The Topics Which Are Used by Jordanian Males and Females in the WhatsApp Statuses}

Figures below highlight the topics being used by both gender groups and shed the lights on the most and least frequent topics being tackled by both genders.

4.1.1 The Topics Which Are Used by Jordanian Females in Their WhatsApp Statuses 


\title{
Jordanian Females
}

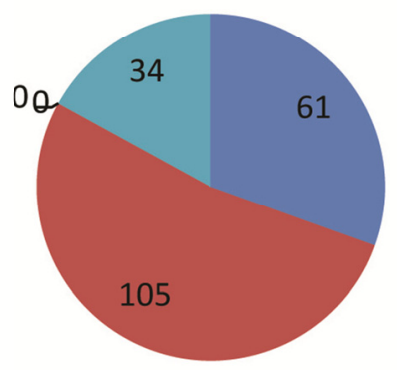

\author{
Social \\ Religious \\ Economic \\ - Political \\ Fixed
}

Figure 1. The distribution of WhatsApp statuses of Jordanian females by topics

Figure 1 highlights the distribution of the major topics used in WhatsApp statuses among Jordanian females of both age groups including the social, religious, economic, political topics and fixed statuses suggested by the mobile itself. The figure also shows that the most frequent topic being used by Jordanian females is the religious topic. The social topic comes second in frequency of use, and the fixed statuses come third whereas the economic and the political topics are the least frequent topics being tackled by Jordanian Females.

\section{Subcategories of Religious Topic}

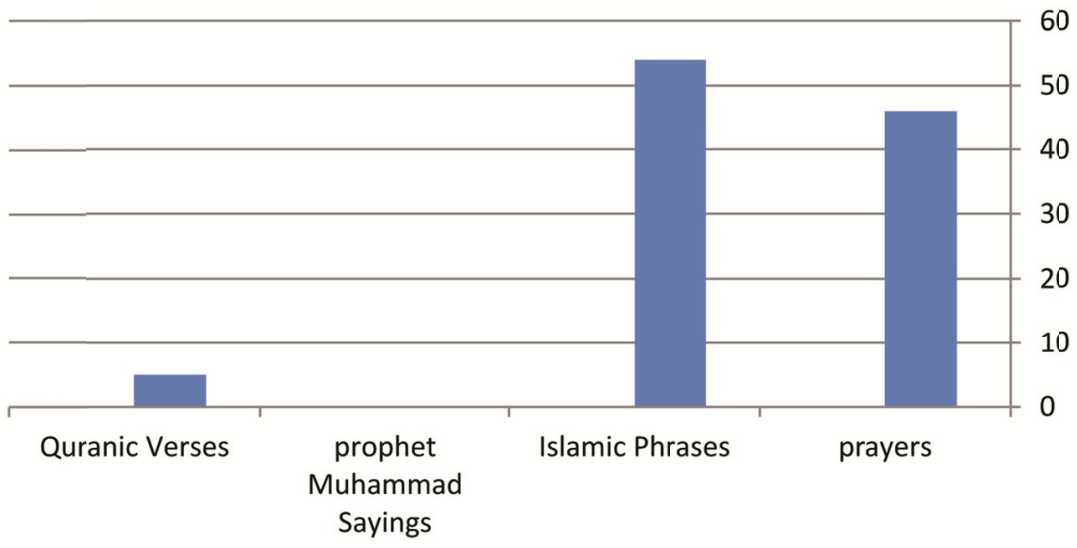

Figure 2. The distribution of the subcategories of the religious topic by Jordanian females

As it is shown in figure 2 that the most frequent religious subcategory being used among Jordanian females is the Islamic Phrases such as /لا اله الا اله محمداً رسول اله laa Pilaaha Pilaa Pallaah Muhammad rasuul Pallaah/ (There is no God but Allah, Muhammad is the Messenger of God), الهوله / laa hawla walaa quwata Pilaa bi laah/ (There is no power but from God), سبحان الله وبحمده سبحان الله العظيمsubћaan Pallaah wa bi hamdih subћaan Pallaah PalYaðৎiim/ (Glory be to Allah and praise Allah, Allah is the Greatest), حسبي الله ونعم الوكيل /hasbija Pallaah wa niSma Palwakiil/ (Allah is sufficient for me and how fine a trustee he is) .

We can attribute this result to the fact that women are consciously aware of their speech and they always like to appear perfect in their society. Also, women are more conscious in their speech and they usually tend to use more standard forms than men. Thus, the religious statuses satisfy this end. (see Drbseh \& Khan, 2013) and (Al-Harahsheh, 2014). 


\subsubsection{The Topics Which Are Used by Jordanian Males in Their WhatsApp Statuses}

\section{Jordanian Males}

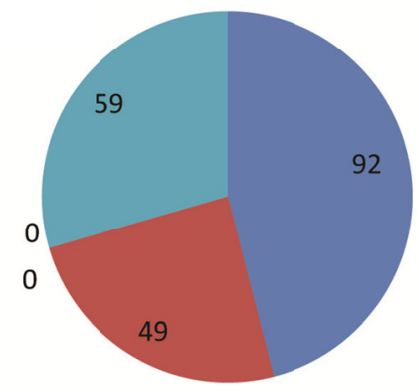

$$
\begin{aligned}
& \text { Social } \\
& \text { Religious } \\
& \text { Economic } \\
& \text { Political } \\
& \text { Fixed }
\end{aligned}
$$

Figure 3. The distribution of WhatsApp statuses of Jordanian males by topics

As it seen above, figure 3 highlights the distribution of the topics being used by Jordanian males of both age groups in their WhatsApp statuses. It shows that most frequent topic being used is the social topic. The topic which comes second in the frequency of use is the fixed statuses suggested by the mobile itself whereas the religious topic is the third and the least frequent topics are the economical and political ones. Figure 4 below shows that the frequent subcategory of the social topic being used by Jordanian males is the emotional feelings including love or hate. For example:(she is beautiful because I love her), ماذا لو اخبرتك انني اخبئه للك حب أعظم مها / maðaa law Paxbartukii Pannanii Puxabi?u lakii hub PaSað'm mimma Puð'hiruhu lakii/ (my hidden love is more than what I show to you), و واذ انتهت ايامنا فتنكري ان الذي يهو اكي هو انا ل wa Piðaa Pintahat Pajaamunaa ftaðakarii Panna Palaðii jahwaakii huwa Panaa/ (if I die, remember that it is me who love you). اقسم الك حين احادثك يصبح, للنبض

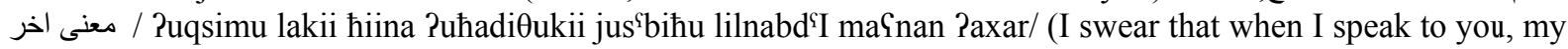
heart's beating has a different meaning), هكذا ساعيش احبك وانت لست لي /hakaðaa saPaYii Puhibukii wa Pantii lastii lii/ (I have always been loving you although you aren't mine).

\section{Social Subcategories}

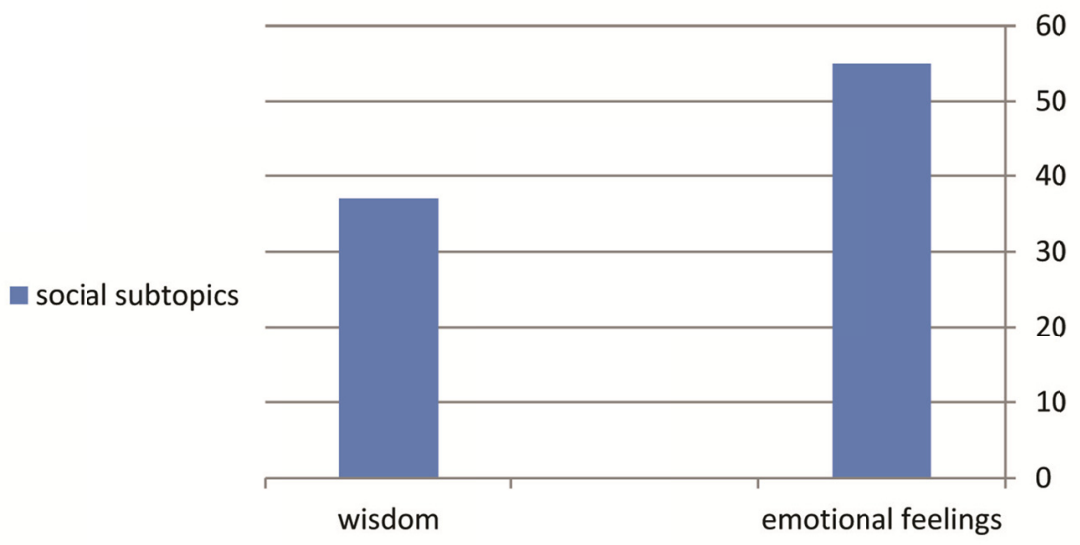

Figure 4. The distribution of the subcategories of the social topic by Jordanian males

The researcher may attribute this result to the idea that males in Jordanian society are free to spell their feelings out especially those towards girls as a matter of courage. Thus, it would be easily for males to write emotional statuses and to be seen by all people. (see Abu-Baker \& Al-Soliman, 2005).

It can be concluded that gender has an essential impact on the topics being used by Jordanian in their WhatsApp statuses. For example, Jordanian females are more conservative in their WhatsApp statuses so that religious is the most frequent topic being used among them. On the other hand, Jordanian males are more opened so that 
they use WhatsApp statuses to socialize and particularly to express their emotional feelings. Moreover, the results show that both gender groups don't use the political nor the economical topics in their statuses.

\subsection{Age Impact on the Topics Being Used in the WhatsApp Statuses}

Figures below highlight the effects of age on the topics being used in the WhatsApp statuses by both gender groups. Each of the gender group is divided into two main age categories; Females who are above 30 years old and females who are under 30 years old. Meanwhile male group is divided into two main categories; males who are above 30 years old and males who are under 30 years old. Figures and tables below illustrate the findings and results.

4.2.1 Topics Being Used by Jordanian Females Whose Age Is Above 30

\section{Females above 30}

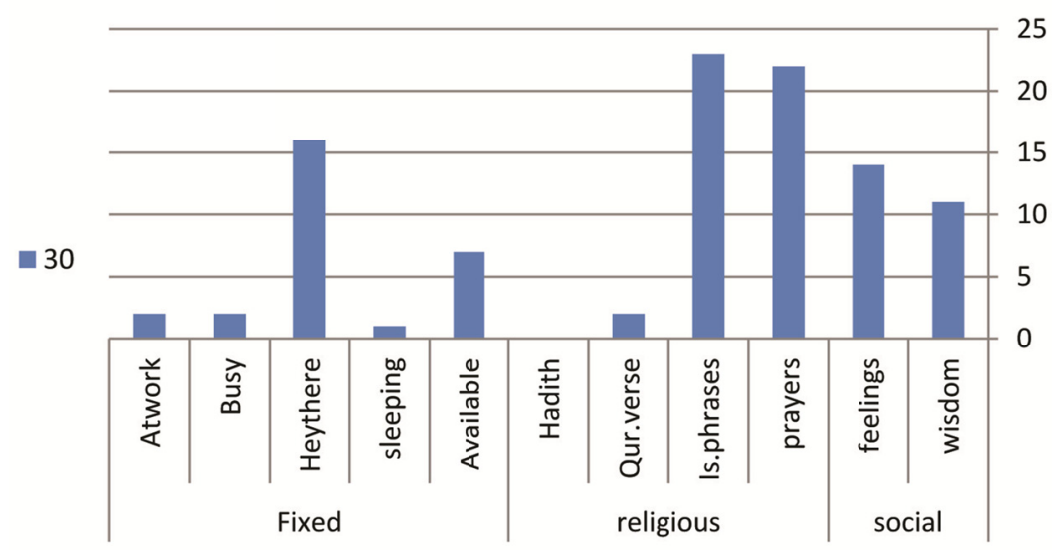

Figure 5 . The distribution of the topics used by +30 -Year-Old Jordanian females

Table 1. Topics being used by +30 Year-Old- Jordanian females

\begin{tabular}{lll}
\hline & +30 -Year-Old Females & \\
\hline Topics & No. & $\%$ \\
Social & 25 & 2.5 \\
Religious & 47 & 4.7 \\
Fixed Statuses & 28 & 2.8 \\
Political & 0 & 0 \\
Economical & 0 & 0 \\
Total of statuses & 100 & $100 \%$ \\
\hline
\end{tabular}

As it is shown above, figurer 5 and table 1 illustrate the findings that the researcher comes up with. It can be noticed that the religious topic is the most frequently used topic among Jordanian female whose age is above (30). The statuses that being conducted for this topic are 47 of the total 100 statuses i.e., (4.7\%). As shown in figure (5), the subcategory of the religious topic which is the Islamic Phrases is the most frequent topic being used by Jordanian females who are above 30 years old. It is worth mentioning that the Islamic phrase (اله اله اله (محمدا رسول اله /laa Pilaaha Pilaa Pallaah Muhammad rasuul Pallaah/ (There is no God but Allah, Muhammad is the Messenger of God) is the most frequent phrase being used, their total is 9 of 23 Islamic phrases were conducted by the researcher. The second topic of the frequency of use is the fixed statuses suggested by the mobile itself , they are 28 stauses out of 100 i.e., (2.8\%) and the most frequent one is "Hey there! Am using WhatsApp" see figure 5. The third topic of the frequency of use is the social topic which has the 25 statuses of the total 100 . As shown in figure 5 the social topic is divided in two subcategories which are emotional feelings and wisdom. The emotional feelings are more frequently used than wisdoms. The emotional feelings include the feelings of those females towards their husbands, children, mothers, or missing feelings toward their dead people. For example عul Gaam wa Pantii bixajr jaa Pummii jaa JamSah mud'iiPah/ (wish you to be fine every year mother who are a lightening candle), انت حبيب عيوني ونور عيوني انتير /Pinta habiib Sujuunii w nuur Gujuunii Pinta/(you are the one whom my eyes love to see you), مشتاق للطفولة /muftaaq lat'ufuulah/(missing the 
childhood), سابقى افتقدك يا والدي /saPabqaa Paftaqiduka jaa waalidii/ (I have always been missing you my father).

The least frequently used topics are the economical and the political ones. Actually the researcher doesn't conduct any statuses relating to these topics.

4.2.2 Topics Being Used by Jordanian Females Whose Age Is Under 30

\section{Females under 30}

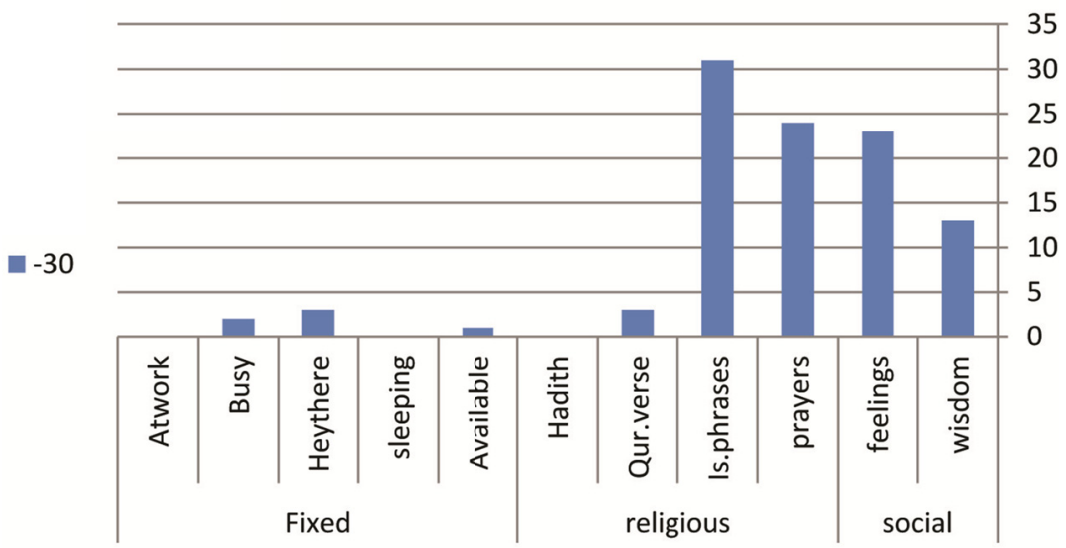

Figure 6 . The distribution of the topics used by -30-Year-Old Jordanian females

Table 2. Topics being used by -30 Year-Old- Jordanian females

\begin{tabular}{lll}
\hline & -30 -Year-Old Females & \\
\hline Topics & No. & $\%$ \\
Social & 36 & 3.6 \\
Religious & 58 & 5.8 \\
Fixed Statuses & 6 & 0.6 \\
Political & 0 & 0 \\
Economical & 0 & 0 \\
Total of statuses & 100 & 100 \\
\hline
\end{tabular}

As it is shown above, figurer 6 and table 3 illustrate the findings that the researcher comes up with. Like +30 -year-old females, it can be noticed that the religious topic is the most frequently used topic among Jordanian female whose age is under 30 . The statuses that being conducted for this topic are 58 of the total 100 statuses i.e., $(5.8 \%)$. As shown in figure (5), like the +30 -year-old females, the subcategory of the religious topic which the Islamic Phrases is the most frequent topic being used by Jordanian females who are under 30 years old. It is worth mentioning that unlike the +30-year-old females, the Islamic phrase (الحمدلة/Ralhamdulillah/ (praise be to Allah) is the most frequent phrase being used, their total is 11 out of 31 Islamic phrases were conducted by the researcher. Unlike the +30 -year-old females, the second topic of the frequency of use among females under 30 is the social topic, they are 36 statuses out of 100 i.e., (3.6\%) and the most frequent sub category is the emotional feelings including being proud of themselves, depressing feelings, or their feelings toward their study or their friends. For example: تفاؤل/tafaa?ul/ (I am feeling optimistic), ما ناكل عسل من الله حلوين /maa naakul Cassal min Pallah hilwiin/ (we are so sweat so that we don't eat honey), كنت مفكرة الدنيا حلوة طلعوا عيوني حلوين /kunt mfakrah

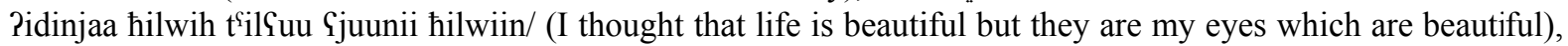
اقسم باله اني فقدت الرغبة في الحياة Pas'daaqah ni؟mah mina Pallah/(friendship is Allah’s gift), الصداقة نعمة من الهه /Puqsim billah Pinnii faqadit Parraybah fii Palhajaah/ (I swear to God, I lost the interest in life).

It is obviously noticed the difference in the feelings that the -30 -year-old females express unlike the + 30 -year-old females and that explains the impact of age on the topics being used. The third topic of the frequency of use is the fixed statuses suggested by the mobile itself, they are only 6 statuses out of 100 . The least frequency used topics are the economical and the political ones. Actually the researcher doesn't conduct any statuses relating to these topics.

It can be concluded that age factor is found to influence the distribution of topics being used in statuses. The 
majority of statuses of both age groups are religious, for the researcher, this might be attributed to the fact that Jordanian females tend to use religion-related expressions and talk about religious issue because females tend to be conservative and polite in their speech and that refers to their own face protection needs. Thus, religious topic satisfies this end. On the other hand, the impact of age on the topics being used among Jordanian females is obviously noticed. For example, while the second frequent topic among +30 -year-old females is the fixed statuses suggested by the mobile itself such as busy, Hey there! am using WhatsApp, At work, and so on, it is the social topic which is found the second frequent topic used among -30-year-old females. For the researcher, this can be attributed to the fact that younger people are more sociable and interactive than older people (Al-Rababa'h \& Malkawi, 2012). In addition, the difference in the topics of the emotional feelings being expressed by both age groups is found. For example, the feelings of the +30 -year-old females are towards their families (husband, daughter, mother, father, etc.) whereas the feelings being expressed by the young females are being proud of themselves, being optimistic, or feelings towards friendship, or feelings towards their study, etc.).

4.2.3 Topics Being Used by Jordanian Males Whose Age Is Above 30

\section{males above 30}

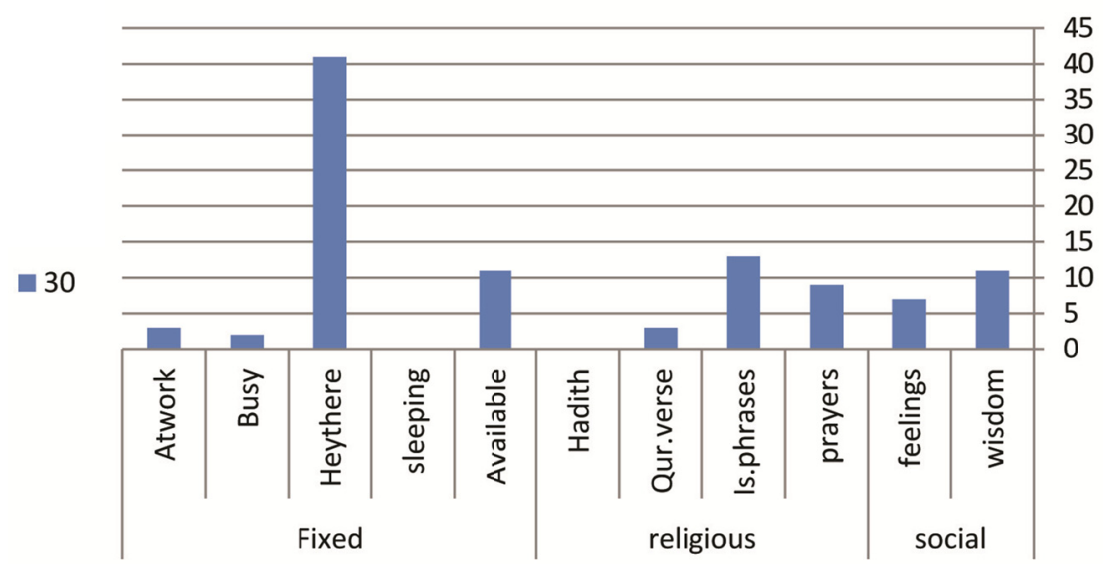

Figure 7. The distribution of the topics used by +30 -Year-Old Jordanian males

Table 3. Topics being used by +30 Year-Old- Jordanian males

\begin{tabular}{lll}
\hline & +30 -Year-Old Males & \\
\hline Topics & No. & $\%$ \\
Social & 18 & 1.8 \\
Religious & 25 & 2.5 \\
Fixed Statuses & 57 & 5.7 \\
Political & 0 & 0 \\
Economical & 0 & 0 \\
Total of statuses & 100 & $100 \%$ \\
\hline
\end{tabular}

Figure 7 and table 3 illustrate the distribution and the frequency of use of the topics being used in the WhatsApp statuses. As above, generally speaking, the fixed statuses suggested by the mobile itself occupy the first place of the frequency of use among +30-year-old Jordanian males, they were 57 statuses out of 100 i.e., (5.7\%). Particularly, the fixed status "Hey there! Am using WhatsApp" is the most frequently used status, they are 41 statuses out of 57 fixed statuses. The religious statuses come in the second frequency of use, they are 25 statuses with the percentage of $(2.5 \%)$. The third statuses are the social ones with the total of 18 statuses i.e., $(1.8 \%)$.the least frequent topics being used are the political and the economical ones. The previous findings show that the +30 -year-old males aren't socially active on the WhatsApp messenger. This can be attributed to the fact that males who are above 30 are busy workers. Thus, they don't have time to change their statuses always. 


\subsubsection{Topics Being Used by Jordanian Males whose Age Is Under 30}

\section{Males under 30}

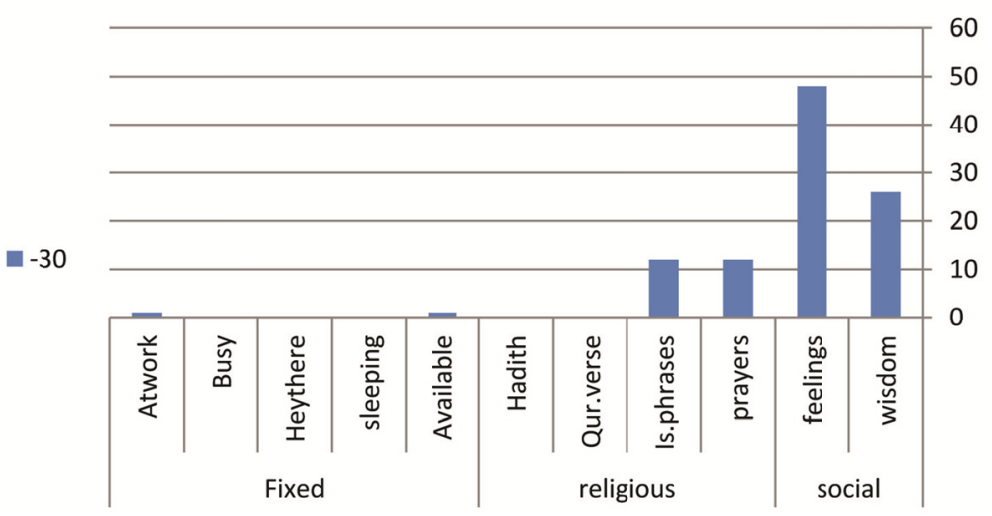

Figure 8 . The distribution of the topics used by -30 -Year-Old Jordanian males

Table 4. Topics being used by -30 Year-Old- Jordanian males

\begin{tabular}{lll}
\hline & -30 -Year-Old Males \\
\hline Topics & No. & $\%$ \\
Social & 74 & 7.4 \\
Religious & 24 & 2.4 \\
Fixed Statuses & 2 & 0.2 \\
Political & 0 & 0 \\
Economical & 0 & 0 \\
Total of statuses & 100 & $100 \%$ \\
\hline
\end{tabular}

Figure 8 and table 4 confirm the fact that Jordanian young males used the WhatsApp messenger to socialize. As shown in table 4 , the most frequently used topic among -30-year-old Jordanian males is the social topic. The findings above show that 74 statuses related to the social topic being conducted out of the total 100 statuses with the percentage of (7.4\%). Figure 8 shows that the social topic is divided into two main subcategories which are emotional feelings and wisdoms. Also, the figure shows that the emotional feelings subcategory is the most قالت له الاسود يليق بك فال: لا يليق بي الاسود الا وانتي بالابض الى 48 statuses were conducted such as جانبي /qalat lahuu PalPaswad jaliiq bika qaala laa jaliiq bii PalPaswad Pilla waPantii bilPabjad Pilaa dzaanibii/ (she told him that the black color is suitable for him, he replied: it will be beautiful if you wear the white wedding dress beside me), اخبروه بانه اول واخر امنياتي في العام الجديد/Paxbiruuhu biPannahu Pawwal wa Paaxir Pumnijjatii fii

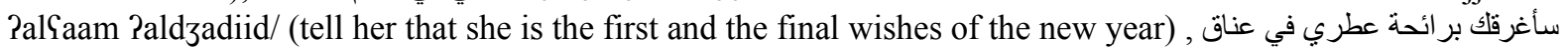

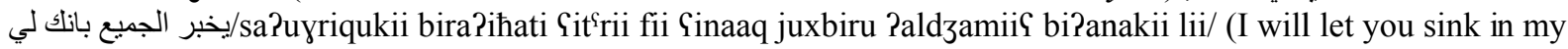
perfume in a hug that tells everyone you are mine), احبك وقمر الليل يشهد باروحي /Puhibukii wa qamar Pallajil jafhad ja ruufhii/ (oh my soul!, I love you and the moon witnesses).

It is obviously noticed that the dominant feelings used among young males are those related to love. For the researcher this finding can be attributed to the fact that Jordanian males are free to spell their feelings out towards their beloved girls. Also, it can be said that young male tend to express their feelings loudly to signal for power and masculinity i.e., to convey connotation of masculinity (see Al-Rababa'h \& Malkawi, 2012).

\section{Conclusion}

The purpose of this study is to investigate the WhatsApp statuses as used by Jordanian people from a sociolinguistic point of view. It attempts to examine the use of the WhatsApp statuses in relation to the impact of gender and age on the topic being used. After the discussion, the researcher concludes that most frequently topic used in the WhatsApp statuses among Jordanian females is the religious topic whereas the most frequently topic used in the WhatsApp statuses among Jordanian males is the social topic. Also, in both gender groups, the economical and the political topics are the least frequently used topics. Moreover, age has an essential impact on the topics being used by Jordanian people of both gender groups. For example, the most frequent topic by +30 -year-old females is the religious topic along with the -30 -year-old female where the most frequent topic is the religious. However, the big difference between these two age groups is in the use of the fixed statuses 
suggested by the mobile itself. For instance, The fixed statuses which are used by the +30 -year -old females are 28 whereas they are only 6 fixed statuses being used by-30-year-old females. Also, the fixed statuses are the second frequently used topic among +30 -year-old females whereas they are the third frequently used topic among -30-year-old females. On the other hand, the role of age is apparently clear among males. For example, the most frequent topic being used among +30 -year-old Jordanian males is the fixed statuses suggested by the mobile itself whereas the most frequent topic being used among -30-year-old Jordanian males is the social topic. Also, in both age groups of both genders, the least frequently used topics are the economic and the political ones.

\section{References}

Abu-Baker, K., \& Al-Soliman, L. (2005). The Impact of Social Values on the Psychology of Gender among Arab Couples: A View from Psychotherapy. The Israel Journal of Psychiatry and Related Sciences, 42(2), 106-115.

Al Rousan, R., Abdul Aziz, N., \& Christopher, A. (2014). "Where Are You?" The Communicative Functions of Saudi Students' Text Messaging. International Journal of English Linguistics, 4(3). http://dx.doi.org/10.5539/ijel.v4n3p23

Al Shezawi, R. (2012). The Effectiveness of Arabic and English Code-Switching Using WhatsApp Mobile Program. Two groups of Omani females. A paper presented in the 11th Annual Research Conference. University of Birmingham. Retrieved http://www.birmingham.ac.uk/Documents/college-social-sciences/education/events/research-conference-20 12--plan.pdf

Al-Azzam, B., \& Al-Quran, M. (2009). Phone Ring Tones In Jordan: A Sociolinguistic Analysis. International Journal of Academic Research, 1(2), 226-231.

Al-Harahsheh, A. (2014). Language and Gender Differences in Jordanian Spoken Arabic: A Sociolinguistics Perspective. Theory and Practice in Language Studies, 4(5), 872-882. https://doi.org/10.4304/tpls.4.5.872-882

Ali Rababa`h, M., \& Malkawi, N. (2012). Men's And Women's Language: Inquiries about Health in Jordanian Arabic. European Scientific Journal, 8(10).

Al-khatib, M., \& Sabbah, E. (2008). Language Choice in Mobile Text Messages among Jordanian University Students. SKY Journal of Linguistics, 21, 37-65.

Badran, R. (2014). The Sociolinguistics Of Mobile Texting Used By Jordanian Adults: A case study of Female texting using whatsApp (unpublished master's thesis). Jordan university of science and technology, Irbid, Jordan.

Castells, M., Fernandez-Ardevol, M., Qiu, J., \& Sey, A. (2006). Mobile communication and society: A global perspective. Cambridge, MA: MIT Press.

Crystal, D. (2001). Language and the Internet. Cambridge: Cambridge University Press. https://doi.org/10.1017/CBO9781139164771

Drbseh, M., \& Abdul Aziz, K. (2013). The language of ladies at the Capital of Jordan. International Journal of Scientific and Research Publications, 3(9).

Farghal, M., \& Al-Khatib, M. (2001). Jordanian Students' Responses to Compliments: A Pilot Study. Journal of Pragmatics, 33, 1485-1502. http://dx.doi.org/ 10.1016/S0378-2166(01)00006-6

Katz, J., \& Aakhus, M. (Eds.). (2002). Perpetual Contact: Mobile Communication, Private Talk, Public Performance. Cambridge: Cambridge University Press. https://doi.org/10.1017/CBO9780511489471

Klimsa, P., Colona, G., Ispandriarno, L., Sasinska-Klas, T., Döring, N., \& Hellwig, K. (2006). Generation SMS:An empirical, 4 country study carried out in Germany, Poland, Peru, and Indonesia. Retrieved from http://km.meme.hokudai.ac.jp/people/jantke/Publications/2007/2007_TUI-IfMK-DB-29.pdf

Lakoff, R. (1975). Language and Women's Place. New York: Harper \& Row.

Lamoureaux, S. (2011). Message in A Mobile. Mixed-Messages, Tales of Missing, and Mobile Communities At The University Of Khartoum. African Studies Centre \& Langaa Publishers: Leiden.

Milroy, J., \& Milroy, L. (1978). Belfast: Change and Variation in an urban vernacular. In P. Trudgill (Ed.), Sociolinguistic Patterns in British English (pp. 45-57). London: Arnold. 


\section{Copyrights}

Copyright for this article is retained by the author(s), with first publication rights granted to the journal.

This is an open-access article distributed under the terms and conditions of the Creative Commons Attribution license (http://creativecommons.org/licenses/by/4.0/). 